\title{
Nonlinear controls on evapotranspiration in arctic coastal wetlands
}

\author{
A. K. Liljedahl ${ }^{1,2}$, L. D. Hinzman ${ }^{1}$, Y. Harazono ${ }^{1,3}$, D. Zona ${ }^{4,8}$, C. E. Tweedie ${ }^{5}$, R. D. Hollister ${ }^{6}$, R. Engstrom $^{7}$, and \\ W. C. Oechel ${ }^{8}$ \\ ${ }^{1}$ International Arctic Research Center, University of Alaska Fairbanks, Fairbanks, AK-99775, USA \\ ${ }^{2}$ Water and Environmental Research Center, University of Alaska Fairbanks, Fairbanks, AK-99775, USA \\ ${ }^{3}$ Osaka Prefecture University, Sakai, Osaka-599-8531, Japan \\ ${ }^{4}$ Research Group of Plant and Vegetation Ecology, University of Antwerp, B-2610 Wilrijk, Belgium \\ ${ }^{5}$ Department of Biology, University of Texas at El Paso, El Paso, TX-79968, USA \\ ${ }^{6}$ Department of Biology, Grand Valley State University, Allendale, MI-49401, USA \\ ${ }^{7}$ Department of Geography, The George Washington University, Washington, DC-20052, USA \\ ${ }^{8}$ Department of Biology, San Diego State University, San Diego, CA-92182, USA
}

Received: 1 June 2011 - Published in Biogeosciences Discuss.: 5 July 2011

Revised: 6 November 2011 - Accepted: 7 November 2011 - Published: 18 November 2011

\begin{abstract}
Projected increases in air temperature and precipitation due to climate change in Arctic wetlands could dramatically affect ecosystem function. As a consequence, it is important to define controls on evapotranspiration, the major pathway of water loss from these systems. We quantified the multi-year controls on midday Arctic coastal wetland evapotranspiration, measured with the eddy covariance method at two vegetated, drained thaw lake basins near Barrow, Alaska. Variations in near-surface soil moisture and atmospheric vapor pressure deficits were found to have nonlinear effects on midday evapotranspiration rates. Vapor pressure deficits (VPD) near $0.3 \mathrm{kPa}$ appeared to be an important hydrological threshold, allowing latent heat flux to persistently exceed sensible heat flux. Dry (compared to wet) soils increased bulk surface resistance (water-limited). Wet soils favored ground heat flux and therefore limited the energy available to sensible and latent heat flux (energy-limited). Thus, midday evapotranspiration was suppressed from both dry and wet soils but through different mechanisms. We also found that wet soils (ponding excluded) combined with large VPD, resulted in an increased bulk surface resistance and therefore suppressing evapotranspiration below its potential rate (Priestley-Taylor $\alpha<1.26$ ). This was likely caused by the limited ability of mosses to transfer moisture during large atmospheric demands. Ultimately, in addition to net radiation, the various controlling factors on midday evapotranspiration (i.e., near-surface soil moisture, atmospheric vapor pressure,
\end{abstract}

Correspondence to: A. K. Liljedahl (akliljedahl@alaska.edu) and the limited ability of saturated mosses to transfer water during high VPD) resulted in an average evapotranspiration rate of up to $75 \%$ of the potential evapotranspiration rate. These multiple limitations on midday evapotranspiration rates have the potential to moderate interannual variation of total evapotranspiration and reduce excessive water loss in a warmer climate. Combined with the prevailing maritime winds and projected increases in precipitation, these curbing mechanisms will likely prevent extensive future soil drying and hence maintain the presence of coastal wetlands.

\section{Introduction}

The response of Arctic wetland hydrology to projected climate warming is uncertain. Evapotranspiration is the least understood component in the hydrologic cycle (Kane et al., 1989, 1992; Vörösmarty et al., 2001; Woo et al., 2008), though regional studies have proposed both increased (Lafleur, 1993) and unchanged (Rouse et al., 1992) future evapotranspiration rates in Arctic coastal wetlands. Evapotranspiration is the major pathway for water loss from the flat tundra landscape (Rovansek et al., 1996; Mendez et al., 1998; Bowling et al., 2003). A region that has for a long time sequestered carbon will shift to a carbon source if soil drying occurs (Oechel et al., 1998; Olivas et al., 2010) and thus, causing a positive feedback to global climate warming.

A vast majority of extremely low-gradient tundra is located within $135 \mathrm{~km}$ of the Arctic Ocean (Walker et al., 2005; Minke et al., 2007). The summer climate of the coastal zone is controlled by a steady mesoscale phenomenon - a nearly

Published by Copernicus Publications on behalf of the European Geosciences Union. 
24-h sea breeze (Moritz, 1977; Walsh, 1977; Kozo, 1979, 1982), resulting in low diurnal temperature fluctuations and low atmospheric vapor pressure deficits (VPD). All components of the coastal wetland energy balance, except net radiation, depend on wind direction, with cold, moist maritime air suppressing evapotranspiration losses (Rouse et al., 1987). One may expect the sea breeze to continue in a warmer climate, though the fate of future evapotranspiration rates from coastal wetlands is uncertain.

Measurement of energy fluxes in arctic environments is challenging due to climatic and logistical constraints. Hence, most field studies are of relatively short duration. There are several field studies of arctic surface energy exchange (see Eugster et al., 2000) and water balance (see Kane and Yang, 2004), but few studies have conducted multi-year analyses of evapotranspiration measured using the eddy covariance technique.

Here we present results from one of the longest time series of flux measurements available for any arctic ecosystem, represented by two vegetated, drained thaw lake basins (five summers at one site; three summers in an adjacent site) on the Arctic Coastal Plain of Alaska. Our objective is to define mechanisms controlling midday evapotranspiration rates from seasonally inundated arctic coastal wetlands. We hypothesize that the evapotranspiration experiences multiple controls apart from surface net radiation. Defining these controls is important in order to refine our understanding of the hydrologic regime and the role of tundra ecosystems in global climate feedbacks.

\section{Background}

Extremely low-relief wetlands represent a significant portion $\left(>400000 \mathrm{~km}^{2}\right)$ of the pan-Arctic landscape (Walker et al., 2005) and are unique in that they exist in an environment with a desert-like annual precipitation $\left(\sim 250 \mathrm{~mm} \mathrm{yr}^{-1}\right)$. Sparse summer runoff (Brown et al., 1968; Kane et al., 2008) limits the summer net water balance to summer precipitation minus evapotranspiration. A negative summer net water balance is common (Mendez et al., 1998), but this is offset by an annual replenishment of water from snowmelt (Rovansek et al., 1996). The abundance of snowmelt water results in extensive surface inundation during the first week following snowmelt (Bowling et al., 2003; Woo et al., 2006). Spring runoff is not generated until surface stores are replenished (Rovansek et al., 1996; Bowling and Lettenmaier, 2010). Accordingly, evapotranspiration is the major pathway for water loss in summer and also affects the lateral exports of water.

Evapotranspiration from wet and moist tundra ecosystems of the North Slope of Alaska is estimated to be 0.8$4.2 \mathrm{~mm} \mathrm{day}^{-1}$, resulting in estimated annual totals ranging from 70 to $190 \mathrm{~mm}$ (see summary by Vourlitis and Oechel, 1997). A majority (55 to $85 \%$ ) of this evapotranspiration is represented by evaporation from moss and open water (see review by Engstrom et al., 2006), even though bryophytes receive only $10-20 \%$ of direct solar radiation during a clear summer day (Miller and Tieszen, 1972). Upward migration of water in Sphagnum moss, attributed to capillary flow, has been shown to occur from water tables located at $0.2 \mathrm{~m}$ depth (Hayward and Clymo, 1982; Price et al., 2009). Capillary water flow in moss, and hence moss evaporation, is negligible at water potentials below $-0.1 \mathrm{MPa}$ (Hayward and Clymo, 1982). In comparison, stomatal closure due to water stress by the typical vascular plants occurs at soil water potentials of $-0.4 \mathrm{MPa}$ (Arctophila fulva) to $-1.2 \mathrm{MPa}$ (Carex aquatilis) (Stoner and Miller, 1975; Johnson and Caldwell, 1975). Total transpiration is closely related to Leaf Area Index (LAI), as stomatal closure is rare at wet, coastal Arctic sites (Miller and Tieszen, 1972). However, plant-scale studies have also shown that the conductance of tundra plants can be reduced by leaf cell water stress, induced by vapor pressure gradients between the leaf and the ambient air that range from 0.7 to $2 \mathrm{kPa}$ (Johnson and Caldwell, 1975). Tundra bryophytes are extremely sensitive to air vapor pressure deficits, due to the direct changes in tissue water content (Oechel and Sveinbjörnsson, 1978).

The effect of maritime air mass on surface energy partitioning has been observed in tundra $135 \mathrm{~km}$ inland from the Arctic coast (Harazono et al., 1998). Cold, moisture-laden air along the coast boosts the partitioning of surface energy into sensible heat flux $(H)$, caused by (a) a steep temperature gradient between the ground surface and air, favoring $H$; and (b) a nearly saturated air mass that reduces latent heat flux ( $L E$ ) (Rouse et al., 1987; Lafleur and Rouse, 1988, 1995; Price, 1991; Harazono et al., 1998; Boike et al., 2008). This dynamic explains, at least partly, the observation that despite wet soils, evapotranspiration is generally below its potential rate in coastal arctic wetlands (Rouse et al., 1987; Mendez et al., 1998). However, it is unclear what values in vapor pressure deficits lead to significant changes in surface energy partitioning and evapotranspiration rates.

Soil moisture may also play a major role in tundra surface energy balance partitioning. Surface energy partitioning shifted from being dominated by latent heat in the early season, when the water table was near the ground surface, to being dominated by sensible heat in late summer, when the water table was at $30 \mathrm{~cm}$ depth at a coastal wet and moist herbaceous tundra site (Vourlitis and Oechel, 1997). Further, wet organic soils transfer heat more efficiently than dry organic soils (Farouki, 1981; Hinzman et al., 1991), which, in theory, would leave less net radiation available to sensible and latent heat fluxes. This prompts questions about whether the Arctic wetlands display important controlling mechanisms on the local hydrological system, constraining evapotranspiration rates not only when near-surface conditions are dry, but also when they are wet. 


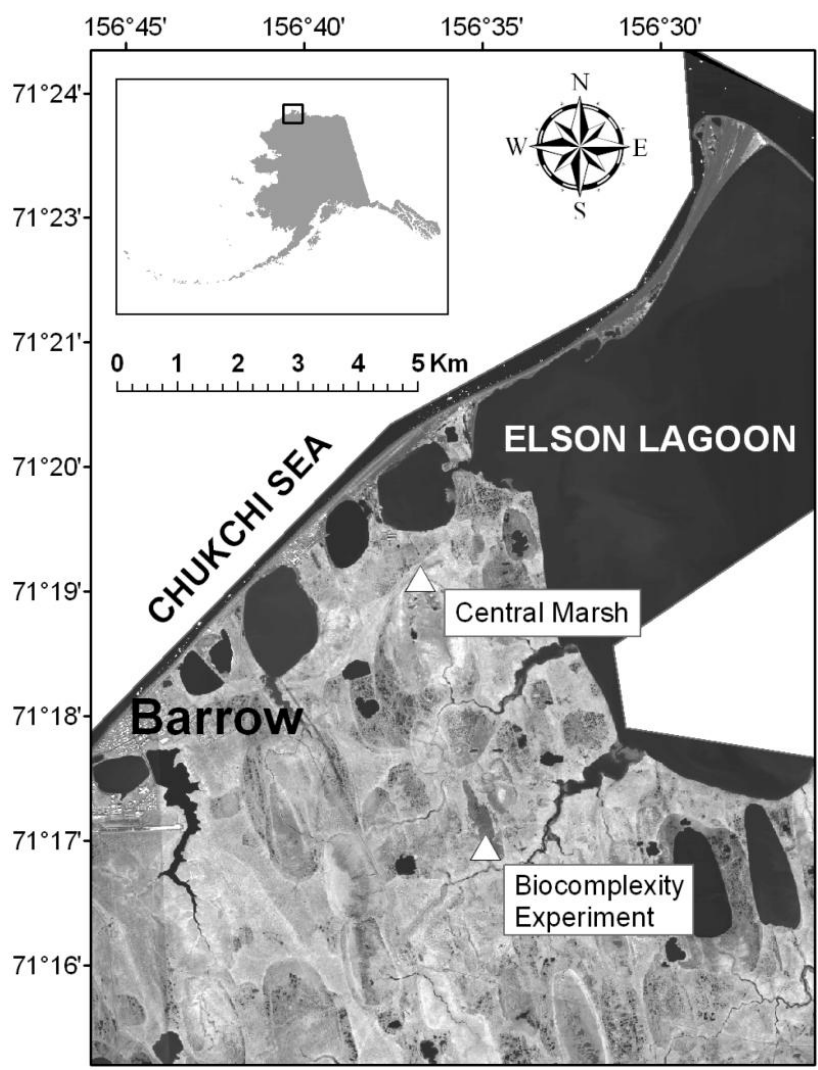

Fig. 1. The Central Marsh (CM) and the Biocomplexity Experiment (BE) sites are located at separate vegetated, drained thaw lake basins within $3 \mathrm{~km}$ of the ocean, outside the town of Barrow, Northern Alaska.

\section{Site description}

The two sites, hereafter referred to as Central Marsh $\left(\mathrm{CM}\right.$, at $71^{\circ} 19^{\prime} 12.5^{\prime \prime} \mathrm{N}, 156^{\circ} 37^{\prime} 20.211^{\prime \prime} \mathrm{W}$, elevation $\left.1 \mathrm{~m}\right)$ and the Biocomplexity Experiment (BE, at $71^{\circ} 16^{\prime} 51.17^{\prime \prime} \mathrm{N}$, $156^{\circ} 35^{\prime} 47.28^{\prime \prime} \mathrm{W}$, elevation $4.5 \mathrm{~m}$ ), are located $4.5 \mathrm{~km}$ apart, and both are only a few kilometers from the ocean near Barrow, Alaska, on the Arctic Coastal Plain (Fig. 1). Mean annual air temperature at Barrow Airport is $-12{ }^{\circ} \mathrm{C}(1977-$ 2009), with a summer (June through August) average of $3.3^{\circ} \mathrm{C}$. A large amount of the annual adjusted precipitation (173 mm, 1977-2009) falls during June through August $(72 \mathrm{~mm})$. Fog and drizzle are common during the summer because the area receives a steady cool, moist wind (mean $5 \mathrm{~m} \mathrm{~s}^{-1}$ ) off the ocean from the east-northeast (Shulski and Wendler, 2007). The BE site is located in the control treatment of a large-scale hydrologic manipulation experiment that began in 2007 (identified as the South site in the work by Zona et al., 2009). Unlike the other treatments, this site did not have manipulated water tables.

The BE and CM sites are representative of vegetated, drained thaw lake basins that appear to have drained be- tween 50 and $300 \mathrm{yr}$ ago (Hinkel et al., 2003). The sites are poorly drained and are characterized by wet meadow tundra with Typic Aquiturbels soils (Bockheim et al., 1999) underlain by $600 \mathrm{~m}$ thick permafrost (Brown and Johnson, 1965). Low-centered ice-wedge polygons are found at the vegetated, drained thaw lake basin while high-centered icewedge polygons cover the upland areas of the watershed. Vegetated, drained thaw lake basins (Mackay, 1963) occupy approximately $26 \%$ of the Arctic Coastal Plain (Hinkel et al., 2005) and $50 \%$ of the Barrow Peninsula north of $\sim 71^{\circ}$ latitude (Hinkel et al., 2003). Longer-term ( $>2 \mathrm{yr}$ ) energy balance measurements of vegetated, drained thaw lakes are limited, constraining our understanding of interannual controls of evapotranspiration rates from this vast region.

Non-vascular vegetation contributes significantly to biomass and land cover (Webber, 1974, 1978; Oechel and Sveinbjörnsson, 1978; Rastorfer, 1978). Bryophytes represent between 60 and $95 \%$ of the overall live biomass in similar wet meadow communities (Tieszen, 1978), with much of the variation due to small-scale heterogeneity associated with micro-topography (Tieszen, 1978; Hollister and Flaherty, 2010). Across the BE drained lake bed, mosses represent most of the live above-ground biomass (Zona et al., $2009,2010,2011)$. Up to $60 \%$ of the ecosystem's net daytime $\mathrm{CO}_{2}$ uptake at the end of the growing season at $\mathrm{BE}$ is represented by Sphagnum (Zona et al., 2011). Accordingly, controls on evapotranspiration rates from this landscape are likely dominated by moss evaporation processes.

The sites differ somewhat in vascular plant composition, LAI (green biomass, unless otherwise stated), and the amount of standing dead biomass (which is defined as attached or upright dead plant matter). Arctophila fulva is the dominant vascular plant species at the CM site, where vegetation is also represented by sedges, mosses, and lichens. LAI at the CM site reached 1.4 in mid-August of 2001 (Mano, 2003). Mid-August LAI reached 0.58 in 2006 at the $\mathrm{BE}$ vegetated, drained lake, where the vascular plant coverage is dominated by Carex aquatilis (Zona et al., 2011). Sedges at the BE site did not experience water stress in midJuly of 2008 (P. Olivas, unpublished data). Standing dead leaf biomass in the Barrow area reaches $1.23 \mathrm{~m}^{2} \mathrm{~m}^{-2}$ (Dennis et al., 1978). The CM site has a larger abundance of standing dead biomass than the BE site (personal observation). End of growing season plant senescence extends from the end of August to late September (Myers and Pitelka, 1979).

The sparseness of live subsurface material at depths greater than $25 \mathrm{~cm}$ at Barrow suggests that the cold temperatures near the bottom of the active layer limit vascular root growth (Dennis and Johnson, 1970). Moss may reach a thickness of $20 \mathrm{~cm}$ at wet sites, but the bulk of their living biomass is usually within $\sim 1 \mathrm{~cm}$ of the soil surface (Engstrom et al., 2005). The rate of thaw is at its highest in early summer and the maximum thaw depth (active layer depth) is reached in late August/September. The active layer depth at a nearby 
drained lake basin varied from 19 to $62 \mathrm{~cm}$ ( $36 \mathrm{~cm}$ mean) from 1995-2009, while the mean active layer depth at the BE site was $30 \mathrm{~cm}$ in 2006 and $26 \mathrm{~cm}$ in 2007 and 2008 (Shiklomanov et al., 2010).

\section{Methods}

The controls on midday evapotranspiration rates were assessed through surface energy balance partitioning, the McNaughton and Jarvis $\Omega$-factor, and by solving for parameters in the Penman-Monteith and the Priestley-Taylor equations. The results were then analyzed in the context of soil moisture and meteorological conditions.

\subsection{Measurements}

We collected summer (June through August) measurements for five years (1999-2003) at the CM site and for three years (2006-2008) at the BE site. Energy flux measurements were taken at a $10 \mathrm{~Hz}$ sampling interval using an eddy covariance system. The path length of our anemometer and gas analyzer sensor at $\mathrm{CM}$ was $10 \mathrm{~cm}$, and the separation distance between the center of the sonic anemometer and the open-path IRGA sensors was $16 \mathrm{~cm}$. The three components of wind speed, air temperature, and water vapor concentration from these sensors were recorded on a magneto-optical disc by a digital recorder (Teac, DRM3). At BE, the sensor separation of the Li-7500 and WindMasterPro was $10 \mathrm{~cm}$. The Li-7500 was calibrated every two to four weeks, using ultra high purity nitrogen as zero and a dew point generator $(\mathrm{Li}-610, \mathrm{Li}-$ COR) that produced an air stream with a known water vapor dew point. Micrometeorological variables were sampled on a data logger every $5 \mathrm{~s}(\mathrm{CM})$ or $10 \mathrm{~s}(\mathrm{BE})$, and then averaged every $30 \mathrm{~min}$. Additional descriptions of the measurements and data analysis are presented in the work of Harazono et al. (2003) and Zona et al. (2009).

Measurements of volumetric water content (VWC) at two locations within the CM drained lake basin were taken in 2000-2003 by inserting a $7 \mathrm{~cm}$ Vitel probe (Hydra soil moisture probe, Vitel Inc.) vertically into the ground. The instrument was calibrated through comparison to multiple ovendried soil samples (Engstrom et al., 2005). The CM site was often inundated in early summer. Such events are presented here as $100 \%$ VWC to indicate ponding.

Hourly atmospheric air pressure for the years 1999-2003 were obtained from the NCDC web archive (http://cdo.ncdc. noaa.gov/cgi-bin/cdo/cdostnsearch.pl) and used in the calculations of the psychrometric constant. Long-term records of daily precipitation and air temperature were retrieved from the National Climatic Data Center (NCDC) web archive for the Barrow Airport (STN 700260, WBAN 27502, http:// www.ncdc.noaa.gov/cgi-bin/res40.pl?page=gsod.html). The characteristic increase in net radiation $\left(R_{\mathrm{n}}\right)$ defined the start date of the summer. We adjusted the daily precipitation to account for gage undercatch, according to Yang et al. (1998). Snow accumulation was retrieved from the Circumpolar Active Layer Monitoring program (http://www. udel.edu/Geography/calm/).

\subsection{Eddy covariance calculations}

We calculated flux of heat and momentum at $30 \mathrm{~min}$. intervals, according to typical covariance calculation procedures. The following corrections were applied (Harazono et al., 2003; Zona et al., 2009): humidity effect on the sonic thermometry (Kaimal and Gaynor, 1991); effects of path length and sensor separation on the spectrum for high-frequency flux ranges (Moore, 1986); air density effects (Webb et al., 1980; Leuning et al., 1982); and coordinate rotation (Tanner and Thurtell, 1969). We removed calculated flux during rain, fog, and low wind, which may have caused a bias (i.e., reduced representation of low evapotranspiration rates). Extreme amplitudes in the flux data (greater than three times the average) were removed. At the BE site, fluxes of latent heat, sensible heat and momentum were calculated using the EdiRe program and software (version 1.4.3.1169, Robert Clement, University of Edinburgh). No gap-filling was performed when analyzing the bulk parameters and energy flux ratios. Midday represented half-hourly values around solar noon (defined as $\pm 2 \mathrm{~h}$ from local solar noon, $\sim 14: 00$ Alaska Standard Time). Extreme (greater than six times the average) amplitudes in bulk parameters were removed. All analyses, except the total daily evapotranspiration, represent nongap-filled midday values. For daily evapotranspiration rates, gap filling was performed for missing data $(<3.5$ consecutive hours), using linear interpolation. The ending date of the study periods was 31 August and the start date in each year was, at the earliest, the first day after the snowmelt completion, although the effective dates depended upon the available data.

\subsection{Soil moisture analysis}

Unfrozen soil moisture, in percent saturation, was estimated from volumetric water content measurements at $10 \mathrm{~cm}$ depth at the BE site. The spring peak in soil moisture was assumed to represent saturated conditions ( $100 \%$, all micro and macro pore spaces filled with liquid water). In winter, the organic soil was assumed to have $6 \%$ saturation (Hinzman et al., 1991). Soil water potential $(\psi)$ was calculated by fitting a curve, after van Genuchten (1980), to a measured water potential sequence (WP4-T, Decagon Devices) from a surface organic moss layer sampled at the BE site.

\subsection{Analysis of resistances and equilibrium evaporation}

The Penman-Monteith equation (Monteith, 1973) is expressed in terms of aerodynamic $\left(r_{\mathrm{a}}\right)$ and bulk surface resistance $\left(r_{\mathrm{c}}\right)$ : 


$$
L E=\frac{s Q_{\mathrm{a}}+\frac{\rho C_{p}\left[e_{\mathrm{s}}\left(T_{\mathrm{a}}\right)-e_{\mathrm{a}}\right]}{r_{\mathrm{a}}}}{s+\gamma\left[1+r_{\mathrm{c}} / r_{\mathrm{a}}\right]}
$$

where $s$ is the slope of the saturation vapor pressure curve versus temperature modified from Brutsaert (1982); $Q_{\mathrm{a}}$ is available energy $\left(\mathrm{W} \mathrm{m}^{-2}\right) ; \gamma$ is the psychrometric constant $\left(\mathrm{kPa} \mathrm{K}^{-1}\right) ; \rho$ the air density $\left(\mathrm{kg} \mathrm{m}^{-3}\right) ; C_{p}$ is the specific heat capacity of air $\left(\mathrm{kJ} \mathrm{kg}^{-1} \mathrm{~K}^{-1}\right)$ at constant pressure; $e_{\mathrm{S}}$ is the saturation vapor pressure $(\mathrm{kPa})$ at $T_{\mathrm{a}}$, which is the ambient air temperature $(\mathrm{K})$; and $e_{\mathrm{a}}$ is the air vapor pressure $(\mathrm{kPa})$. Shallow ponded water can represent a significant portion $(<50 \%)$ of the net radiation partitioning (Harazono et al., 1998). Therefore, we defined $Q_{\mathrm{a}}$ as the sum of sensible $(H)$ and latent heat $(L E)$ fluxes, since no water temperature measurements were obtained. The aerodynamic resistance, $r_{\mathrm{a}}\left(\mathrm{s} \mathrm{m}^{-1}\right)$, is calculated from Eq. (2) following Monteith (1973), with an additional term on the right side representing the laminar boundary layer resistance from Thom (1975) and Lafleur and Rouse (1988):

$r_{\mathrm{a}}=\frac{u}{u^{* 2}}+\frac{4}{u^{*}}$

where $u^{*}$ is friction velocity $\left(\mathrm{m} \mathrm{s}^{-1}\right)$ obtained by eddy covariance measurements and $u$ is wind speed. From here forward, the sum of the aerodynamic and laminar boundary layer resistance in Eq. (2) is referred to as aerodynamic resistance $\left(r_{\mathrm{a}}\right)$. The aerodynamic resistance is the bulk meteorological descriptor of the role of atmospheric turbulence in evaporation.

Isothermal resistance, $r_{\mathrm{i}},\left(\mathrm{m} \mathrm{s}^{-1}\right)$ was originally defined by Monteith (1965) and is sometimes referred to as the climatological resistance. It is the ratio of the water vapor deficit to available energy at the canopy:

$r_{\mathrm{i}}=\frac{\rho \cdot C_{p}}{\gamma} \frac{\left[e_{\mathrm{s}}-e_{\mathrm{a}}\right]}{Q_{\mathrm{a}}} \quad$ (Stewart and Thom, 1973)

Equations (1), (3), and the Bowen ratio, $\beta$, which is the ratio of sensible over latent heat, can be combined to solve for the bulk surface resistance, $r_{\mathrm{c}}\left(\mathrm{m} \mathrm{s}^{-1}\right)$ :

$r_{\mathrm{c}}=(1+\beta) r_{\mathrm{i}}+\left(\beta \frac{s}{\gamma}-1\right) r_{\mathrm{a}}$

The bulk surface resistance characterizes the control of water loss by vascular plants, non-vascular vegetation, and bare ground.

The bulk surface resistance approaches zero either because the surface boundary layer becomes saturated and VPD $=0$ or the air travels over an unsaturated surface with constant $r_{\mathrm{c}}$ and the moisture deficit in the air becomes equal to the value of the surface. A $r_{\mathrm{c}}$ close to 0 results in the Penman-Monteith Equation (Monteith, 1973) collapsing into:

$L E=\alpha\left(\frac{s}{s+\gamma}\right) Q_{\mathrm{a}} \quad$ (Priestley and Taylor, 1972)

which is known as the Priestley-Taylor equation. The evapotranspiration is referred to as "equilibrium" when $\alpha$ equals one, which is most commonly achieved when VPD $=0$ (note that equilibrium rates can also be measured over unsaturated surfaces and VPD $>0$ ). This method assumes that latent heat flux depends only upon the absolute temperature and available energy. Results from a variety of arctic sites, both wet and dry, indicate that latent heat flux is often above the equilibrium rate (see Engstrom et al., 2002), as originally suggested by Priestley and Taylor (1972) at a non-water-limited grassland. Large-scale mixing of the planetary boundary layer and the entrainment of drier air from above the mixed layer results in evaporation over saturated surfaces greater than the "equilibrium" rate (McNaughton and Jarvis, 1983; DeBruin, 1983). DeBruin (1983) indicates that $\alpha$ is a function of wind speed, surface roughness, and bulk surface resistance. Here we defined the potential evapotranspiration by setting the $\alpha$-value to 1.26 (Priestley and Taylor, 1972).

The McNaughton and Jarvis $\Omega$-factor sets the relative importance of $r_{\mathrm{c}}$ and $r_{\mathrm{a}}$ :

$\Omega=\left(1+\frac{s}{s+\gamma} \frac{r_{\mathrm{c}}}{r_{\mathrm{a}}}\right)^{-1}$

A vigorous turbulent mixing of the air mass suppresses $\Omega$ by promoting increased VPD at the surface. Limited atmospheric mixing results in $\Omega$ approaching unity (McNaughton and Jarvis, 1983). However, $\Omega$ will approach 0 as long as $r_{\mathrm{c}} \gg r_{\mathrm{a}}$. In general, VPD is the main driver of evapotranspiration when $\Omega$ is low, while net radiation has the dominant control when $\Omega$ is near 1 .

\section{Results}

\subsection{Meteorological and hydrologic conditions}

Analyzed measurements represented the thawed season through August (1999-2003 and 2006-2008). Mean air temperature (June-August, $3.2^{\circ} \mathrm{C}$ ) and precipitation (JuneSeptember $86 \mathrm{~mm})$ were near the long-term means $\left(3.4^{\circ} \mathrm{C}\right.$ and $99 \mathrm{~mm}$, respectively, from 1979-2008), though large interannual variations occurred (Table 1). Summer 2007 brought unusually high air temperatures $\left(5.4{ }^{\circ} \mathrm{C}\right)$ and low precipitation $(24 \mathrm{~mm})$. Most of the 2007 summer precipitation occurred in a single event in mid-August. During all study periods, $77 \%$ of daily precipitation rates were less than $2 \mathrm{~mm} \mathrm{day}^{-1}$. Trace observations $(<0.13 \mathrm{~mm})$ represented $33 \%$ of all recorded events. Accumulated winter precipitation ranged from 93 to $158 \mathrm{~mm}$ of snow water equivalent (SWE).

The maritime nature of both sites led to low variability in VPD and air temperature. Mean daily VPD was $0.08 \mathrm{kPa}$, with a typical diurnal min and max of 0.02 and $0.17 \mathrm{kPa}$, respectively. Mean midday VPD was similar during all years $(0.10-0.13 \mathrm{kPa})$ except during summer of 2007 , when VPD was higher $(0.17 \mathrm{kPa})$ (Table 1$)$. The maximum VPD 
Table 1. Meteorological conditions during the study period (1999-2008), including Snow Water Equivalent (SWE) prior to snowmelt; total precipitation from June through September; mean air temperature June through August; mean midday (12:00 through 16:00) air vapor pressure deficit (VPD); and the number of days that experienced a VPD above $0.3 \mathrm{kPa}$. Mean precipitation and air temperature, 1999-2008 ( $86 \mathrm{~mm}$ and $3.2^{\circ} \mathrm{C}$, respectively), were near the long-term (1979-2008) conditions of $99 \mathrm{~mm}$ and $3.4{ }^{\circ} \mathrm{C}$, respectively. The end of the study period was 31 August (Julian day 242).

\begin{tabular}{lrrrrrrrrr}
\hline & 1999 & 2000 & 2001 & 2002 & 2003 & 2006 & 2007 & 2008 & Mean \\
\hline SWE (mm) & 122 & 113 & 123 & 93 & 95 & 137 & 98 & 158 & $117 \pm 23$ \\
Precipitation, June-September (mm) & 82 & 128 & 124 & 114 & 72 & 72 & 24 & 68 & $86 \pm 35$ \\
Mean air temperature, June-August $\left({ }^{\circ} \mathrm{C}\right)$ & 4.2 & 3.1 & 2.1 & 2.3 & 2.5 & 2.9 & 5.4 & 3.3 & $3.2 \pm 3.2$ \\
Mean midday VPD, June-August (kPa) & 0.12 & 0.13 & 0.1 & 0.12 & 0.12 & 0.11 & 0.17 & 0.12 & $0.12 \pm 0.02$ \\
VPD > 0.3 kPa, June-August (days) & 12 & 10 & 14 & 9 & 8 & 10 & 13 & 10 & $11 \pm 2$ \\
Start study period (Julian-Day) & 163 & 163 & 164 & 156 & 158 & 162 & 162 & 169 & $162 \pm 4$ \\
\hline
\end{tabular}

Table 2. Differences in midday (12:00 through 16:00) energy balance partitioning, bulk parameters, and air conditions during offshore (from land to ocean) and onshore (from ocean to land) winds at the CM site during the thawed season, 1999-2003. The temperature gradient $(\Delta T)$ represents the air minus the ground surface temperature (sensor located at $1 \mathrm{~cm}$ depth).

\begin{tabular}{lcc}
\hline & Offshore & Onshore \\
\hline$L E / R_{\mathrm{n}}$ & $0.33 \pm 0.17$ & $0.28 \pm 0.14$ \\
$H / R_{\mathrm{n}}$ & $0.22 \pm 0.12$ & $0.35 \pm 0.14$ \\
$G / R_{\mathrm{n}}$ & $0.22 \pm 0.08$ & $0.15 \pm 0.07$ \\
$\beta$ & $0.87 \pm 0.82$ & $1.37 \pm 0.64$ \\
$\alpha$ & $1.08 \pm 0.24$ & $0.95 \pm 0.21$ \\
$\Delta T\left({ }^{\circ} \mathrm{C}\right)$ & $2.3 \pm 3.5$ & $-1.3 \pm 3.8$ \\
$\mathrm{VPD}(\mathrm{kPa})$ & $0.21 \pm 0.22$ & $0.12 \pm 0.13$ \\
\hline
\end{tabular}

recorded was $1.76 \mathrm{kPa}$, but days exceeding VPDs of $0.3 \mathrm{kPa}$ were few ( 8 to 14 days per summer).

Onshore summer winds, defined as winds originating from between 1-135 and 225-360 degrees, occurred $89 \%$ of the time (1999-2008). Air during onshore winds was colder than the ground surface (Table 2). Offshore winds (from land to sea) typically produced higher VPDs and air temperatures than onshore winds, reversing the typical midday temperature gradient between the air and the ground surface.

The moss surface and organic soils remained close to saturation throughout the study periods, with the exception of 2007 (Fig. 2). The soils within the vegetated, drained lake basins were unusually dry in late July 2007 (when the water table dropped below $15 \mathrm{~cm}$ depth). Snowmelt water recharged the drained lake soil water storage in spring. Water table measurements at the BE drained lake basin show a multi-week long ponding period following the snowmelt (note that the water table measurements do not capture the start of the inundation). About $10 \mathrm{~cm}$ of water accumulated above the ground surface following snowmelt. The drained lake basins also experienced inundation in late summer (2001 and 2008), resulting in an inundation for at least half of the summer's duration. No soil water measurements were made in summer 1999, but the near-normal precipitation $(82 \mathrm{~mm})$ suggests wet soil conditions.

\subsection{Surface energy exchange}

Energy balance closure was not complete (CM $80 \%$ and BE $95 \%$, Table 3), though it was comparable to other tundra and grassland ecosystems reported by Eugster et al. (2000), Wilson et al. (2002), Cava et al. (2008), and Ryu et al. (2008). A major portion of the midday surface energy balance was partitioned into sensible heat flux (CM $35 \%$ and BE $48 \%$ ), resulting in a mean midday Bowen ratio above unity at both sites (1.40 at CM and BE). Latent heat flux represented $29 \%$ and $35 \%$, and ground heat flux averaged $16 \%$ and $12 \%$, at $\mathrm{CM}$ and $\mathrm{BE}$, respectively. A plot of the seasonal and interannual variations in midday energy partitioning across the thawed season suggests a somewhat consistent partitioning into $L E$ (Fig. 3a, b) despite large interannual differences in soil moisture (Fig. 2).

Mean midday evapotranspiration (ET) rates showed large day-to-day variations, which were also found in total daily ET. Measured total evapotranspiration ranged from 0 to $4.7 \mathrm{~mm} \mathrm{day}^{-1}$ (mean $1.5 \mathrm{~mm} \mathrm{day}^{-1}$ ), and 0.2 to $3.4 \mathrm{~mm} \mathrm{day}^{-1}$ (mean $1.9 \mathrm{~mm} \mathrm{day}^{-1}$ ), at the CM (311 days) and BE (46 days) sites, respectively. The high McNaughton and Jarvis $\Omega$-factor (CM 0.74 and BE 0.75 ) suggests that net radiation was the main control on evapotranspiration rates. Overall mean midday evapotranspiration was near or below the equilibrium rate (CM 0.94 and BE 0.88) (Table 3). Overall average evapotranspiration rates of $75 \%(\mathrm{CM})$ and $70 \%$ (BE) of the potential rate $(\alpha 1.26)$ indicate additional controls than net radiation alone.

The effect of soil moisture on Priestley-Taylor $\alpha$ was gradual. Approximately $64 \%(P<0.01$, probability that correlation is zero) of the variance in the Priestley-Taylor $\alpha$ was correlated to the near-surface soil moisture (Fig. 4a). Additional comparisons were possible by focusing on a time period (20 July through 12 August) that displayed unusually dry soils $(\Psi<-0.13 \mathrm{MPa})$ in 2007 but that was wet (although not inundated) in the other years (Table 4). In 

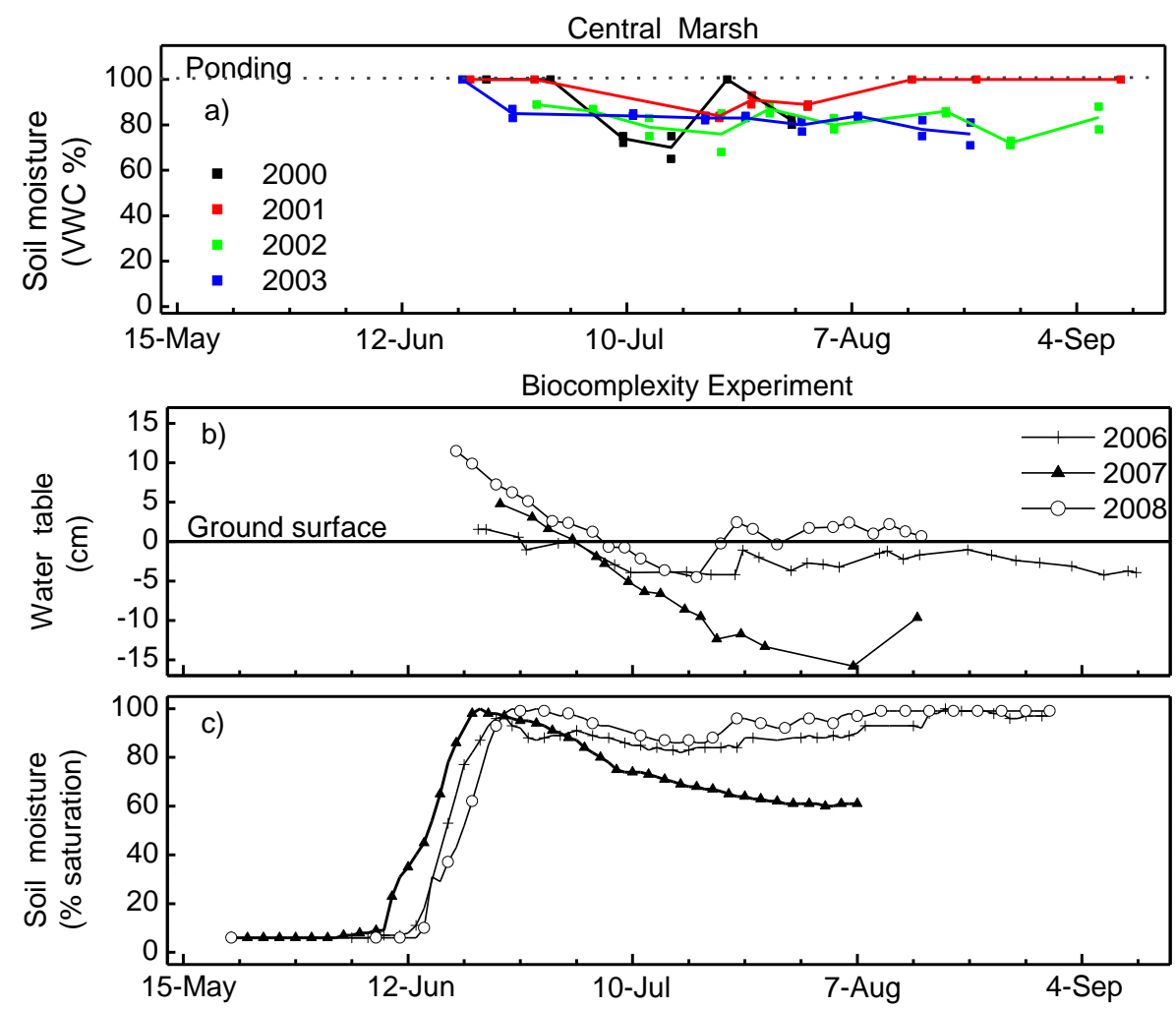

Fig. 2. The soil water status during the study period (no measurements from 1999) at the CM site (a) and the BE site (b and c). Panels (a) and (b) represent multiple locations across the vegetated, drained lake basins, while panel (c) is a continuous record of volumetric soil water content measurements at $10 \mathrm{~cm}$ depth near the BE eddy covariance tower, converted into \% saturation.

Table 3. Mean midday (12:00 through 16:00) energy balance partitioning and bulk parameters at the CM (1999-2003) and BE (20062008) sites during the thawed season (through August).

\begin{tabular}{lcc}
\hline & Central Marsh & Biocomplexity Experiment \\
\hline$L E / R_{\mathrm{n}}$ & $0.29 \pm 0.15$ & $0.35 \pm 0.07$ \\
$H / R_{\mathrm{n}}$ & $0.35 \pm 0.14$ & $0.48 \pm 0.12$ \\
$G / R_{\mathrm{n}}$ & $0.16 \pm 0.07$ & $0.12 \pm 0.05$ \\
Closure & $0.80 \pm 0.23$ & $0.95 \pm 0.13$ \\
$\beta$ & $1.40 \pm 0.67$ & $1.40 \pm 0.39$ \\
$\Omega$ & $0.74 \pm 0.22$ & $0.75 \pm 0.17$ \\
$\alpha$ & $0.94 \pm 0.22$ & $0.88 \pm 0.15$ \\
$r_{\mathrm{c}}\left(\mathrm{s} \mathrm{m}^{-1}\right)$ & $46 \pm 40$ & $46 \pm 38$ \\
$r_{\mathrm{a}}\left(\mathrm{s} \mathrm{m}^{-1}\right)$ & $62 \pm 38$ & $63 \pm 27$ \\
$r_{\mathrm{i}}\left(\mathrm{s} \mathrm{m}^{-1}\right)$ & $14 \pm 14$ & $12 \pm 12$ \\
\hline
\end{tabular}

Closure $=(L E+H+G) / R_{\mathrm{n}}$

addition to decreased Priestley-Taylor $\alpha$-value, the dry soil conditions showed reduced $\Omega$. Bulk surface resistance also responded to dry $\left(r_{\mathrm{c}} 57 \mathrm{~s} \mathrm{~m}^{-1}\right)$ and wet $\left(41 \mathrm{~s} \mathrm{~m}^{-1}\right)$ soils, and displayed a statistically significant trend in summer 2003 and 2007. Accordingly, reduced soil moisture had a suppressing effect on ET.
Despite the differences in Priestley-Taylor $\alpha$ and $r_{\mathrm{c}}$, latesummer partitioning of net radiation into $L E$ was strikingly similar between dry and wet soils (37 and 34\%, respectively). This suggests controls additional to bulk surface resistance for ET. Wet soils increased the partitioning to ground heat flux from $\sim 6 \%$ (dry) to $14 \%$ (saturated conditions) (Fig. 4b, Table 4), which resulted in less energy available to midday $L E$ and $H$.

VPD affected the energy balance partitioning and the Priestley-Taylor $\alpha$. Latent heat fluxes from a wet surface were always slightly larger than sensible heat fluxes (Bowen ratios below unity) if VPDs were above 0.25 (2006), 0.31 (2007), and $0.28 \mathrm{kPa}$ (2008) (Fig. 5). A VPD above these thresholds during wet soils (including ponding) resulted in a Priestley-Taylor $\alpha$ near one or higher. On the other hand, unusually dry soil ( $\Psi<-0.13 \mathrm{MPa}, 20$ July-12 August 2007) resulted in evapotranspiration below the equilibrium rate, despite VPD reaching $1.7 \mathrm{kPa}$. Nevertheless, a VPD $>1.2 \mathrm{kPa}$ resulted in latent heat flux that exceeded the sensible heat flux at dry soils.

A VPD below and above $0.3 \mathrm{kPa}$ resulted in significantly different bulk parameters during wet soils (no ponding) (Table 5). A VPD $>0.3 \mathrm{kPa}$ resulted in slightly increased Priestley-Taylor $\alpha$ and a doubled $r_{\mathrm{c}}$, while $\beta$ and $\Omega$ was 


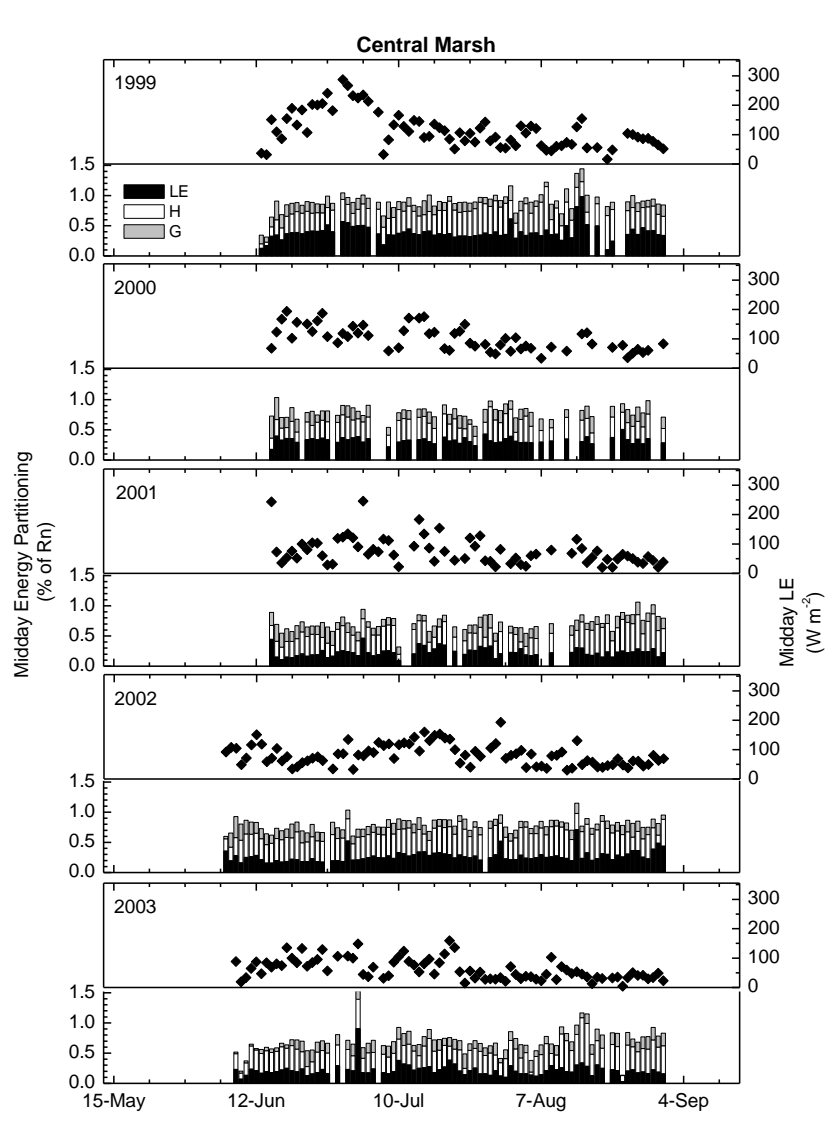

Fig. 3a. The variation in the mean midday energy balance partitioning and evapotranspiration rates during summer 1999-2003 at the Central Marsh site.

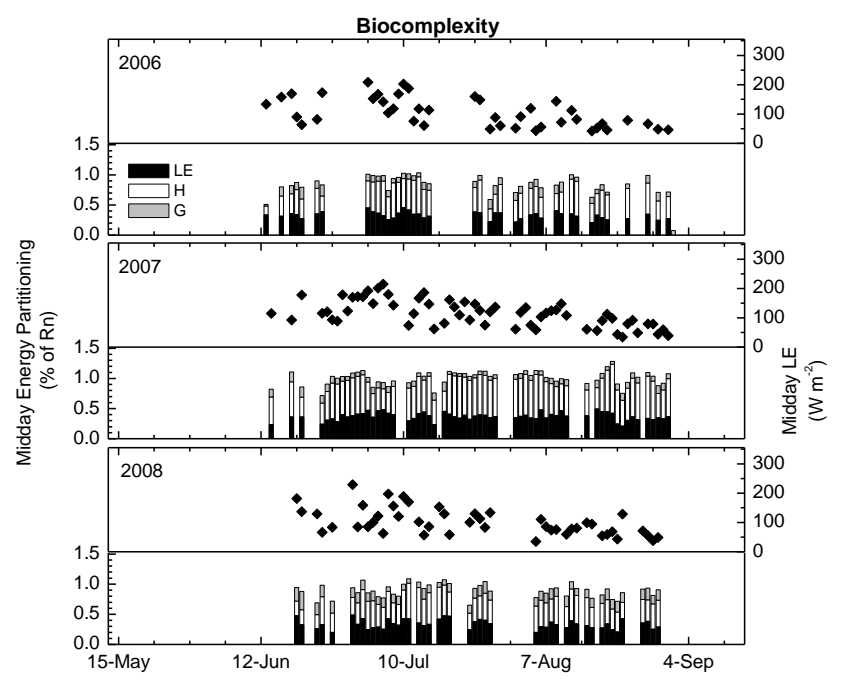

Fig. 3b. The variation in the mean midday energy balance partitioning and evapotranspiration rates during summer 2006-2008 at the Biocomplexity Experiment site.
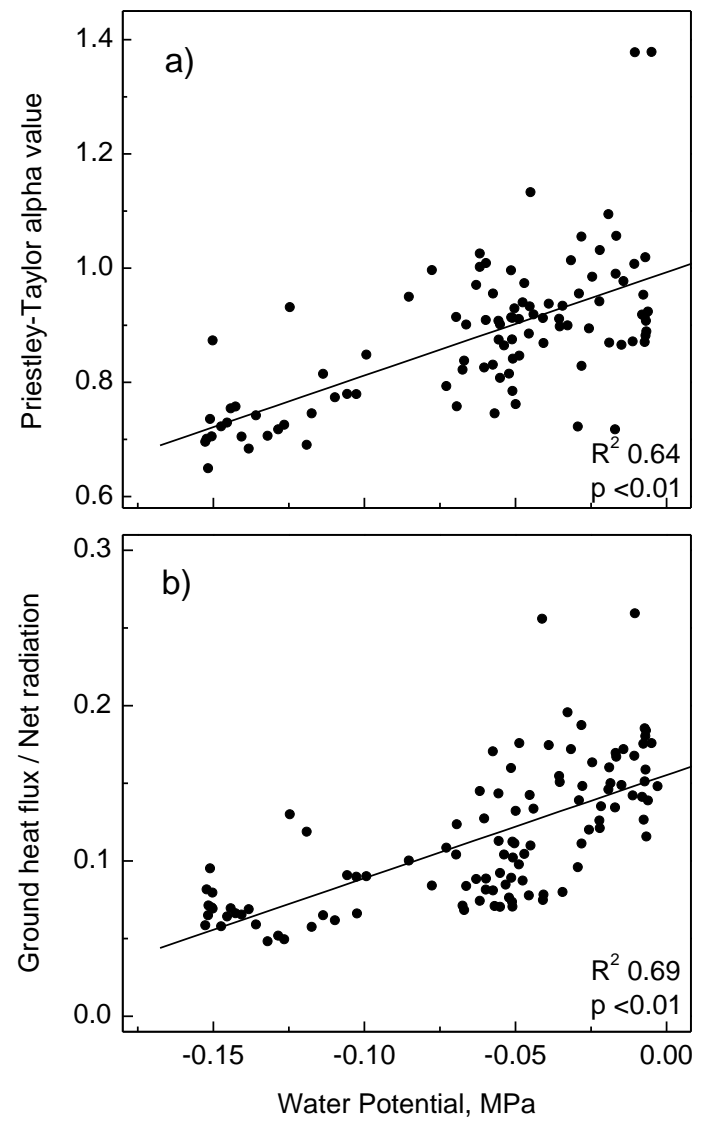

Fig. 4. The rate of evapotranspiration in relation to (a) the equilibrium rate (Priestley-Taylor $\alpha$ ) and (b) near-surface soil moisture at the $\mathrm{BE}$ site. The partitioning of net radiation, $R_{\mathrm{n}}$, into ground heat flux is linearly correlated to near-surface soil moisture $(10 \mathrm{~cm}$ depth). The results represents mean midday values at the BE site.

reduced (15 July-15 August 1999-2003 and 2006). High bulk surface resistance $\left(\sim 100 \mathrm{~s} \mathrm{~m}^{-1}\right)$ often occurred with elevated VPD throughout the study period (Fig. 6). The results suggest that (a) net radiation was the primary control on ET in wet soils when VPD $<0.3 \mathrm{kPa}$ and (b) increased bulk surface resistance suppressed the evapotranspiration during large atmospheric demand even if the soils were wet.

Surface energy partitioning depended on wind direction (Table 2). Onshore winds favored energy partitioning into sensible heat flux ( $\beta 1.37$ ), while the Bowen ratio was slightly below unity during offshore conditions $(0.87)$ at the $\mathrm{CM}$ site. Partitioning into both ground and latent heat increased with offshore winds, while the sensible heat flux portion decreased. No onshore-offshore analysis was performed at the $\mathrm{BE}$ site, as onshore and offshore wind directions represent differing landscape features (drained thaw lake and uplands, respectively).

Two days in late July 2000 showed the cascading effects on meteorological conditions and surface energy balance that were induced by altered wind directions (Fig. 7). The first 
Table 4. Mean midday energy partitioning and bulk parameters at the BE site between 20 July and 12 August during wet, but not inundated (2006 and 2008), and dry (2007) soil moisture conditions. Only days with VPD below $0.3 \mathrm{kPa}$ are included. Dry soil moisture conditions represent $\Psi<-0.13 \mathrm{MPa}$ at $10 \mathrm{~cm}$ depth, which equals a water table at $\sim 15 \mathrm{~cm}$ depth, and no prior precipitation.

\begin{tabular}{lcc}
\hline & Wet & Dry \\
\hline$L E / R_{\mathrm{n}}$ & $0.34 \pm 0.08$ & $0.37 \pm 0.05$ \\
$H / R_{\mathrm{n}}$ & $0.43 \pm 0.10$ & $0.65 \pm 0.06$ \\
$G / R_{\mathrm{n}}$ & $0.14 \pm 0.04$ & $0.06 \pm 0.02$ \\
Closure & $0.91 \pm 0.14$ & $1.08 \pm 0.08$ \\
$\beta$ & $1.33 \pm 0.32$ & $1.79 \pm 0.25$ \\
$\Omega$ & $0.76 \pm 0.08$ & $0.63 \pm 0.04$ \\
$\alpha$ & $0.89 \pm 0.09$ & $0.72 \pm 0.06$ \\
$r_{\mathrm{c}}\left(\mathrm{s} \mathrm{m}^{-1}\right)$ & $41 \pm 22$ & $57 \pm 14$ \\
$r_{\mathrm{a}}\left(\mathrm{s} \mathrm{m}^{-1}\right)$ & $63 \pm 19$ & $48 \pm 10$ \\
$r_{\mathrm{i}}\left(\mathrm{s} \mathrm{m}^{-1}\right)$ & $10 \pm 6$ & $7 \pm 6$ \\
\hline
\end{tabular}

Closure $=(L E+H+G) / R_{\mathrm{n}}$, Dry $=\Psi<-0.13 \mathrm{MPa}$

day represented near-normal meteorological conditions, with onshore winds resulting in an equal partitioning of $L E$ and $H$. Offshore winds occurred during the following day, which resulted in high VPD $(1.3 \mathrm{kPa})$, with $L E$ dominating $H$. The $L E$ exceeded $H$ when the VPD passed $0.37 \mathrm{kPa}$ (see Fig. 7, vertical dashed lines). Conversely, $L E$ and $H$ became equal later in the afternoon when the VPD returned to $0.37 \mathrm{kPa}$. Bulk surface resistance and Priestley-Taylor $\alpha$ responded accordingly, with increasing mean midday bulk surface resistance (from 75 to $128 \mathrm{~s} \mathrm{~m}^{-1}$ ) and increasing Priestley-Taylor $\alpha$ (from 0.84 to 1.03 ).

\section{Discussion}

Our analyses confirm earlier landscape-scale work from coastal Arctic wetlands that relied on Bowen ratio and energy balance techniques as well as plant-scale ecohydrological studies from the Arctic Coastal Plain. The high McNaughton and Jarvis $\Omega$-factor suggests that net radiation was the main control on evapotranspiration rates, but our results show that midday evapotranspiration rates are additionally constrained during both wet and dry near-surface conditions. We concur with previous studies that state the importance of maritime air mass favoring sensible heat (large temperature gradients) and suppressing latent heat flux (low VPD) (Rouse et al., 1987; Lafleur and Rouse, 1988; Price, 1991; Harazono et al., 1998). We also show that near-surface soil moisture conditions and VPD express nonlinear effects on midday evapotranspiration. Ultimately, the various controlling factors (i.e., net radiation; soil moisture; VPD; and, despite wet near-surface soils, bulk surface resistance during high VPD) reduced the evapotranspiration under a range of meteorological and hydrologic conditions, which have the potential to buffer interannual variation of total evapotran-
Table 5. Average midday energy balance partitioning and bulk parameters during VPD below and above $0.3 \mathrm{kPa}$ at the CM (19992003) and BE (2006) sites, during wet, but not inundated, nearsurface soil moisture conditions (15 July-15 August).

\begin{tabular}{lcc}
\hline & \multicolumn{2}{c}{ Wet Soils } \\
& VPD $<0.3 \mathrm{kPa}$ & VPD $>0.3 \mathrm{kPa}$ \\
\hline$L E / R_{\mathrm{n}}$ & $0.30 \pm 0.14$ & $0.36 \pm 0.14$ \\
$H / R_{\mathrm{n}}$ & $0.38 \pm 0.16$ & $0.35 \pm 0.14$ \\
$G / R_{\mathrm{n}}$ & $0.15 \pm 0.08$ & $0.14 \pm 0.07$ \\
Closure & $0.83 \pm 0.21$ & $0.83 \pm 0.19$ \\
$\beta$ & $1.45 \pm 0.61$ & $1.04 \pm 0.53$ \\
$\Omega$ & $0.72 \pm 0.22$ & $0.59 \pm 0.17$ \\
$\alpha$ & $0.89 \pm 0.20$ & $0.91 \pm 0.25$ \\
$r_{\mathrm{c}}\left(\mathrm{s} \mathrm{m}^{-1}\right)$ & $51 \pm 47$ & $114 \pm 61$ \\
$r_{\mathrm{a}}\left(\mathrm{s} \mathrm{m}^{-1}\right)$ & $63 \pm 45$ & $64 \pm 42$ \\
$r_{\mathrm{i}}\left(\mathrm{s} \mathrm{m}^{-1}\right)$ & $13 \pm 12$ & $39 \pm 24$ \\
\hline
\end{tabular}

Wet soils $=\Psi \gg-0.13 \mathrm{MPa}$

spiration. Midday evapotranspiration rates were, on average, $70 \%(\mathrm{BE})$ and $75 \%(\mathrm{CM})$ of the potential rate as defined by a Priestley-Taylor $\alpha$-value of 1.26.

The generally low vapor pressure deficits (mean midday $0.12 \mathrm{kPa}$ ) play an important role in suppressing the evapotranspiration from arctic coastal wetlands. A VPD near $0.3 \mathrm{kPa}$ appears to represent a threshold during wet nearsurface soils (Fig. 5). Above $0.3 \mathrm{kPa}$, latent heat fluxes always dominated sensible heat fluxes, and the evapotranspiration rates always remained near or above the equilibrium rate (Fig. 5, Table 5).

Despite large interannual variations in mean summer air temperature, the number of days exceeding a VPD of $0.3 \mathrm{kPa}$ varied only between 8 (2003) and 14 days (2001). In addition, it was the coldest summer (2001) that had the most days above $0.3 \mathrm{kPa}$, although the two warmest summers (1999 and 2007) trailed closely behind (12 and 13 days, respectively). Hence, warmer mean summer air temperatures did not necessarily mean an increased number of days with VPDs above $0.3 \mathrm{kPa}$.

An increased atmospheric demand favored the partitioning of net radiation into $L E$, but an increased bulk surface resistance - despite wet soils - prevented evapotranspiration from reaching its potential rate $(\alpha \sim 1.26)$ (Table 5). The reduction in $\Omega$ suggests that VPD increased its role in driving evapotranspiration when VPD reached above $0.3 \mathrm{kPa}$. Simultaneously, a VPD $>0.3 \mathrm{kPa}$ more than doubled the bulk surface resistance, which limited any increase in the PriestleyTaylor $\alpha$. The rate of water movement through moss (capillary forces upwards from the water table) is likely not able to support potential evaporation rates. Our landscape-scale findings agree with earlier plot-scale studies of tundra vascular and non-vascular conductance (inverse of resistance) (Johnson and Caldwell, 1975; Oechel and Sveinbjörnsson, 

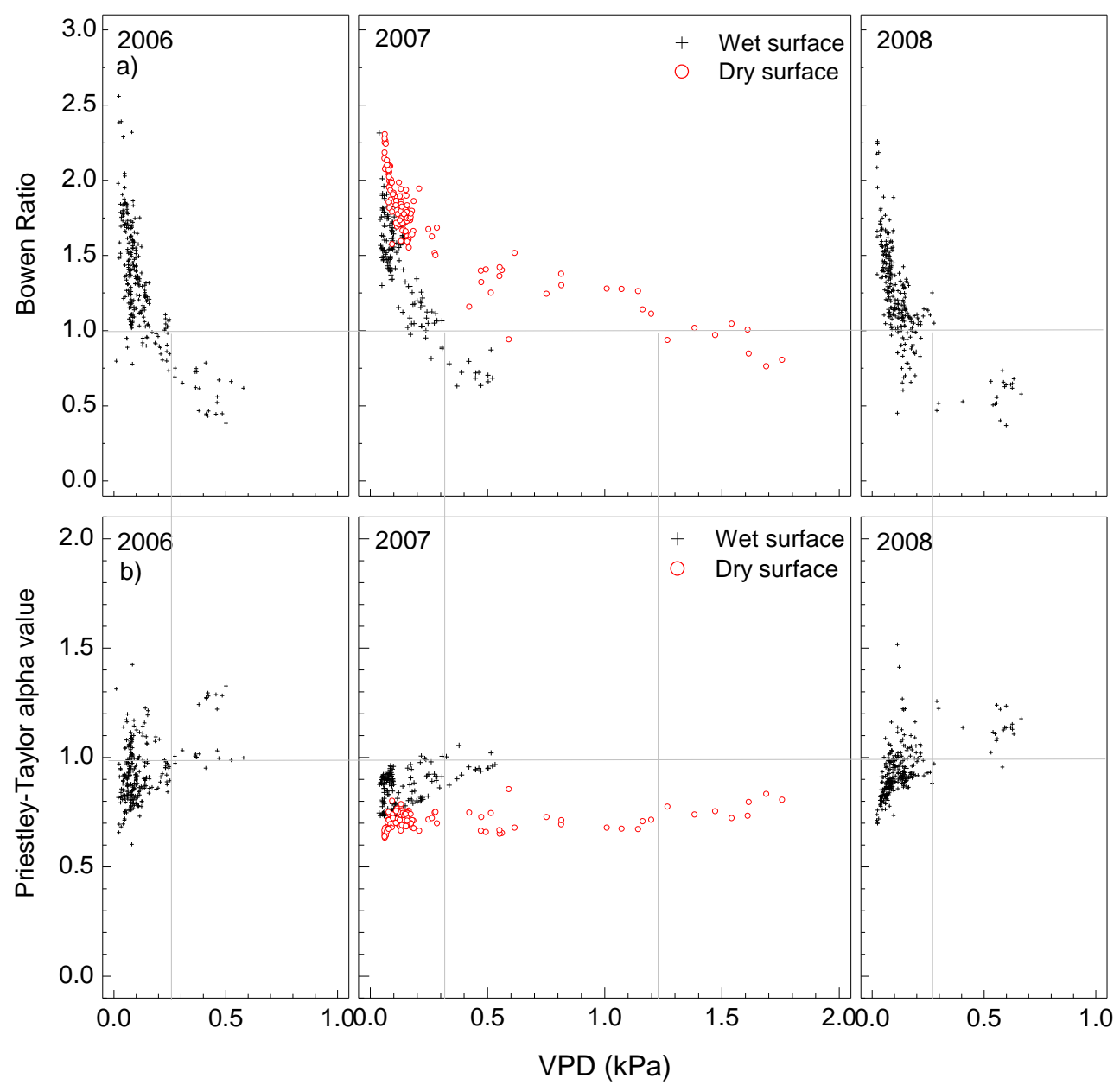

Fig. 5. The relationship between mean hourly air vapor pressure deficit (VPD) and (a) Bowen ratio ( $\beta$ ) or (b) Priestley-Taylor $\alpha$ during differing soil moisture conditions at the BE site, 2006-2008. Dry soils represent a soil water potential $<-0.13 \mathrm{MPa}$ at $10 \mathrm{~cm}$ depth. The vertical dashed lines represent the identified critical value of VPD. VPDs above this threshold resulted in a $\beta<1$ and a Priestley-Taylor $\alpha$ near or above 1 . The identified VPD thresholds were 0.25 (2006), 0.31 (2007), and $0.28 \mathrm{kPa}(2008)$ for wet soils and $1.19 \mathrm{kPa}$ for dry soils (2007).

1978), in which surface cover (despite wet soils) was unable to deliver enough moisture when atmospheric demands were high.

Hence, the evapotranspiration from the two studied vegetated, drained thaw lakes was suppressed during both low and high VPDs, but through differing mechanisms. The lower VPDs present a direct atmospheric constraint as the air is unable to hold much additional moisture. High VPD results in an indirect constraint on evapotranspiration rates through an insufficient transfer rate of water through the moss layer, expressed through an increased bulk surface resistance.

Near-surface soil moisture plays an important role in controlling energy balance in vegetated, drained thaw lake basins. The higher Priestley-Taylor $\alpha$ and the lower bulk surface resistances during high near-surface soil moisture presented reduced constraints on evapotranspiration (Fig. 4a, Table 4). However, the linkage between evapotranspiration and soil moisture appears to be more complex, since the ratio of latent heat flux to net radiation was similar between dry and wet soils during VPDs $<0.3 \mathrm{kPa}$. The increased partitioning into ground heat flux during wet (compared to dry) soils reduced the energy available for midday sensible and latent heat flux - a phenomenon which has also been discussed by McFadden et al. (1998). Not unlike the discussion about the nonlinear controls of VPD on evapotranspiration, we suggest that midday evapotranspiration was suppressed during both dry and wet soils but through differing mechanisms: (a) energy limitations (wet soils) through an increased partitioning of net radiation into ground heat flux and (b) water limitations (dry soils).

The multiple nonlinear controls may moderate the spatial variability in the energy partitioning from different vegetation types. Short-term mid-summer measurements of $L E / R_{\mathrm{n}}$ at tussock, tussock-shrub, shrub, and wet sedge tundra 

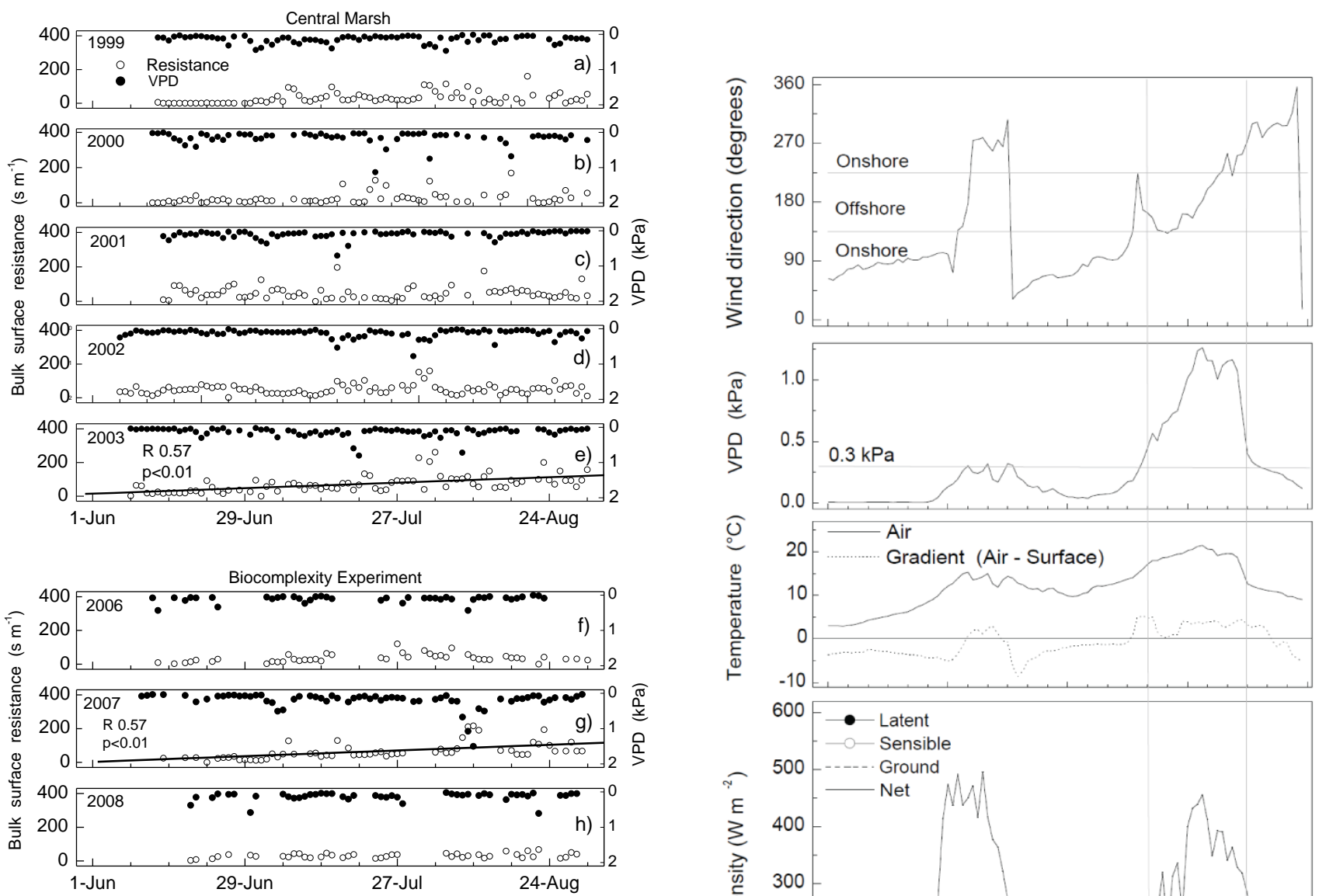

Fig. 6. Mean midday values of bulk surface resistance $\left(r_{\mathrm{c}}\right)$ and VPD at the CM (a-e) and BE (f-h) sites.

ranged from 35 to $42 \%$ (mean 38\%) (McFadden et al., 1998), which is close to our wet and dry mid-summer conditions (34-37\%). It is apparent, however, that there is quite a large variability in $L E / R_{\mathrm{n}}$ between sites and time periods from a multitude of short-term eddy covariance measurements across the North Slope of Alaska (Eugster et al., 2000). Nevertheless, values in $L E / R_{\mathrm{n}}$ and other measures presented in this study, agree well with those reported by Harazono et al. (1998), Eugster et al. (2000), McFadden et al. (1998), and McFadden and Chapin III (2003) of non-shrub coastal sites in Arctic Alaska. Accordingly, the details presented in this study are representative of the Arctic Coastal Plain $(<135 \mathrm{~km}$ from the ocean) even though the energy partitioning (and controls on ET) may show similarities to other locations.

The measurements employed in this study cannot distinguish transpiration from evaporation, but our results can be compared to past findings. Firstly, measured mean ET rates ( 1.5 and $1.9 \mathrm{~mm} \mathrm{day}^{-1}$ ) were more than twice the maximum vascular transpiration $\left(0.2 \mathrm{~mm} \mathrm{day}^{-1}\right)$ estimated by Miller and Tieszen (1972) during peak LAI. Secondly, the measured near-surface soil water potentials never reached the soil water potentials for stomatal closure typical for tundra vascular 
vegetation, a value established by Stoner and Miller (1975) and Johnson and Caldwell (1975). However, soil water potentials surpassed the limit for effective water transport through moss ( $-0.1 \mathrm{MPa})$ in July 2007, which simultaneously saw an increased canopy resistance. Had the vascular vegetation played a dominant role, the observed increase in bulk surface resistance in late summer of 2003 and 2007 would have been less likely. This is because the soil water potential to initiate stomata closure was never reached. In addition, as mosses represent the majority of the live biomass (Zona et al., 2011), one could argue that they represent a key hydrologic pathway between land and atmospheric systems. And, in fact, boreal mosses are known to act as a heat and moisture "rectifier", allowing heat and moisture fluxes to proceed when they are moist, and reducing heat and moisture fluxes under hot and dry conditions when the uppermost moss surfaces are dry (Oechel and Van Cleve, 1986). However, a determination of the amount of transpiration and evaporation on total evapotranspiration would require hydrologic model simulations or isotopic analyses, which are beyond the scope of this study.

Overall, the two vegetated, drained thaw lake basins experienced similar distribution in the energy balance partitioning and bulk parameters, despite differences in weather between the years (Tables 1,3). It should be noted that at least a third of the data from the BE site represents the unusually low precipitation and warm summer of 2007, which may explain differences in site averages. Still, the general partitioning of the energy balance components were similar, even under a relatively wide range of soil moisture conditions. The limited differences between the two sites and the agreement with previous studies suggest that our findings can represent the larger arctic coastal wetland domain.

\section{Future projections}

According to global climate model projections for the mid21 st century, summer air temperature and precipitation will generally increase in the Arctic (Walsh, 2008). Some parts of the land-ocean-atmosphere system are projected to change, but we may also hypothesize resistance in some components of the system. For example, future summer air-mass conditions at the Arctic Coastal Plain are likely to continue to be dominated by a $24-\mathrm{h}$ sea breeze, which brings in moist, cool air that suppresses the evapotranspiration in addition to the nonlinear controls by soil moisture. The future evapotranspiration rates may therefore remain dampened, which is in agreement with Rouse et al. (1992) and in contradiction to the hypothesis of Lafleur (1993).

However, it is challenging to predict long-term effects of climate warming on Arctic wetland hydrology. The integrated response of the coupled permafrost-vegetationhydrology system to a warmer climate could drastically affect the surface energy exchange by curbing or accelerating hydrologic fluxes. The presented results offer an example of this complex system, as evapotranspiration rates integrated across a common landscape type respond nonlinearly to a multitude of controlling factors.

\section{Conclusions}

Evapotranspiration from low-relief, vegetated, drained thaw lake basins experience multiple limitations through nonlinear relationships to atmospheric vapor demand and near-surface soil moisture. We estimated that current midday evapotranspiration rates represent, on average, $<75 \%$ of the potential rates despite the typical saturated near-surface conditions. Midday evapotranspiration was suppressed through different mechanisms: (a) vapor pressure deficits near $0.3 \mathrm{kPa}$ appeared to be an important hydrological threshold, allowing latent heat flux to persistently exceed sensible heat flux; (b) dry compared to wet soils increased the bulk surface resistance (water-limited); (c) wet soils favored ground heat flux and therefore limited the energy available to sensible and latent heat flux (energy-limited); and (d) wet soils (ponding excluded) combined with large atmospheric demands resulted in an increased bulk surface resistance and therefore suppressing the evapotranspiration to below its potential rate (Priestley-Taylor $\alpha<1.26$ ). The latter was likely caused by the limited ability of mosses to transfer moisture during large atmospheric demands. Our landscape-scale analyses agree well with plant-scale ecohydrological studies from the Arctic Coastal Plain. To conclude, there is a resistance in the hydrologic system that curbs soil drying in coastal Arctic wetlands. We propose that the wetness of the arctic coastal wetlands will persist - despite a warming climate - due to the prevailing maritime winds, increased precipitation, and multiple controls on evapotranspiration. Refined projections of future evapotranspiration should also include linkages to geomorphology and vegetation dynamics, which were beyond the scope of this study.

Acknowledgements. We thank Chapin III, F. S., Eugster, W., Kane, D. L., and Fox Jr., J. D., for their reviews of early versions of the manuscript. The Editor and journal reviewers provided valuable comments that we much appreciated. Thanks to Aquierra, A., who provided Fig. 1; Busey, R., for technical assistance; Victorino, G., Villareal, S., and Vargas, S. for assistance with field work; Barrow Arctic Science Consortium for logistical assistance; and Ukpeagvik Iñupiat Corporation for land access to the Barrow Environmental Observatory. Financial support for this research was provided through the National Science Foundation, grants 0652838, 0632263, and 0421588. Any opinions, findings, conclusions, or recommendations expressed are those of the authors and do not necessarily reflect the views of NSF. Mention of specific product names does not constitute endorsement by NSF.

Edited by: P. Stoy 


\section{References}

Bockheim, J. G., Everett, L. R., Hinkel, K. M., Nelson, F. E., and Brown, J.: Soil organic carbon storage and distribution in tundra, Barrow, Alaska, Soil Sci. Soc. Am. J., 63, 934-940, 1999.

Boike, J., Wile, C., and Abniozva, A.: Climatology and summer energy and water balance of polygonal tundra in the Lena River Delta, Siberia, J. Geophys. Res., 113, G03025, doi:10.1029/2007JG000450, 2008.

Bowling, L. C. and Lettenmaier, D. P.: Modeling the effects of lakes and wetlands on the water balance of arctic environments, J. Hydrometeorol., 11, 276-295, 2010.

Bowling, L. C., Kane, D. L., Gieck, R. E., Hinzman, L. D., and Lettenmaier, D. P.: The role of surface storage in a low-gradient Arctic watershed, Water Resour. Res., 39, 1087, doi:10.1029/2002WR001466, 2003.

Brown, J. and Johnson, P. L.: Pedo-ecological investigations at Barrow, Alaska, US Army Cold Regions Research and Engineering Lab., Hanover, USA, Tech. Rep., 159:32, 32 pp., 1965.

Brown, J. R., Dingman, S. L., and Lewellen, R. I.: Hydrology of a drainage basin on the Alaskan Coastal Plain, US Army Cold Regions Research and Engineering Lab., Hanover, USA, Res. Rep., 240, 18 pp., 1968.

Brutsaert, W.: Evaporation into the atmosphere, reprinted 1991, Kluwer Academic Publishers, Dordrecht, The Netherlands, 299 pp., 1982.

Cava, D., Contini, D., Donateo, A., and Martano P.: Analysis of short-term closure of the surface energy balance above short vegetation, Agr. Forest Meteorol., 148, 82-93, 2008.

DeBruin, H. A. R.: A model for the Priestley-Taylor parameter $\alpha$, J. Clim. Appl. Meteorol., 22, 572-578, 1983.

Dennis, J. G. and Johnson, P. L.: Shoot and rhizome-root standing crops of tundra vegetation at Barrow, Alaska, Arctic Alpine Res., 2, 253-266, 1970.

Dennis, J. G., Tieszen, L. L., and Vetter, M. A.: Seasonal dynamics of above- and below-ground production of vacular plants at Barrow, Alaska, in: Vegetation and production ecology of an Alaska Arctic tundra, edited by: Tieszen, L. L., Springer-Verlag, New York, 113-140, 1978.

Engstrom, R., Hope, A. Stow, D. A., Vourlitis, G. L., and Oechel, W. C.: Priestley-Taylor coefficient: Variability and relationship to NDVI in tundra landscapes, J. Am. Water Resour. As., 38, 1647-1659, 2002.

Engstrom, R., Hope, A., Kwon, H., Stow, D., and Zamolodchikov, D.: Spatial distribution of near surface soil moisture and its relationship to microtopography in the Alaskan Arctic coastal plain, Nord. Hydrol., 36, 219-234, 2005.

Engstrom, R., Hope, A., Kwon, H., Harazono, Y., Mano, M., and Oechel, W. C.: Modeling evapotranspiration in Arctic coastal plain ecosystems using a modified BIOME-BGC model, J. Geophys. Res., 111, G02021, doi:10.1029/2005JG000102, 2006.

Eugster, W., Rouse, W., Pielke, R. A., McFadden, J. P., Baldocchi, D. D., Kittel, T. G. F., Chapin III, F. S., Liston, G. E., Vidale, P. L., Vaganov, E., and Chambers, S.: Land-atmosphere energy exchange in Arctic tundra and boreal forest: Available data and feedbacks to climate, Glob. Change Biol., 6, 84-115, 2000.

Farouki, O. T.: Thermal properties of soil, US Army Cold Regions Research and Engineering Lab., Hanover, N.H., Report 81-1, 1981.

Harazono, Y., Yoshimoto, M., Mano, M., Vourlitis, G. L., and
Oechel, W. C.: Characteristics of energy and water budgets over wet sedge and tussock tundra ecosystems at North Slope Alaska, Hydrol. Process., 12, 2163-2183, 1998.

Harazono, Y., Mano, M., Miyata, A., Zulueta, R. C., and Oechel, W. C.: Inter-annual carbon dioxide uptake of a wet sedge tundra ecosystem in the Arctic, Tellus, 55B, 215-231, 2003.

Hayward, P. M. and Clymo, R. S.: Profiles of water-content and pore-size in Sphagnum and peat, and their relation to peat bog ecology, Royal Soc. London Series B-Biol. Sci. Conf. Proceed., 215, 299-325, 1982.

Hinkel, K. M., Eisner, W. R., Bockheim, J. G., Nelson, F. E., Peterson, K. M., and Dai, X.: Spatial extent, age, and carbon stocks in drained thaw lake basins on the Barrow Peninsula, Alaska, Arct. Antarct. Alp. Res., 35, 291-300, 2003.

Hinkel, K. M., Frohn, R. C., Nelson, F. E., Eisner, W. R., and Beck, R. A.: Morphometric and spatial analysis of thaw lakes and drained lake basins in the western Arctic Coastal Plain, Alaska, Permafrost Periglac., 16, 327-341, 2005.

Hinzman, L. D., Kane, D. L., Gieck, R. E., and Everett, K. R.: Hydrological and thermal properties of the active layer in the Alaskan Arctic, Cold Reg. Sci. Technol., 19, 95-110, 1991.

Hollister, R. D. and Flaherty, K. J.: Above- and below-ground plant biomass response to experimental warming in northern Alaska, Appl. Veg. Sci., 13, 1-10, doi:10.1111/j.1654109X.2010.01079.x, 2010.

Johnson, D. A. and Caldwell, M. M.: Gas exchange of four Arctic and Alpine tundra plant species in relation to atmospheric and soil moisture stress, Oecologia, 21, 93-108, 1975.

Kaimal, J. C. and Gaynor, J. E.: Another look at sonic thermometry, Bound. Lay. Meteorol., 56, 401-410, 1991.

Kane, D. L. and Yang, D.: Overview of water balance determinations for high latitude watersheds, in: Northern Research Basins Water Balance, edited by: Kane, D. L. and Yang, D., IAHS, Oxfordshire, UK, 1-12, 2004.

Kane, D. L., Hinzman, L. D., Benson, C. S., and Everett, K. R.: Hydrology of Imnavait Creek, an watershed, Holarctic Ecol., 12, 262-269, 1989.

Kane, D. L., Hinzman, L. D., Woo, M.-K., and Everett, K. R.: Arctic hydrology and climate change, in: Arctic Ecosystem in a Changing Climate, edited by: Chapin III, F. S., Jeffries, R. L., Reynolds, J. E., Shaver, G. R., and Svoboda, J., Academic, San Diego, CA, 35-57, 1992.

Kane, D. L., Gieck, R. E., and Hinzman, L. D.: Water balance for a low-gradient watershed in Northern Alaska, in: Proceedings of the Ninth International Conference on Permafrost, edited by: Kane, D. L. and Hinkel, K. M., University of Alaska Fairbanks, AK, 883-888, 2008.

Kozo, T. L.: Evidence for sea breezes on the Alaskan Beaufort Sea coast, Geophys. Res. Lett., 6, 849-852, 1979.

Kozo, T. L.: An observational study of sea breezes along the Alaskan Beaufort Sea coast: Part 1, J. Appl. Meteorol., 21, 891905, 1982.

Lafleur, P. M.: Potential water balance response to climatic warming: The case of a coastal wetland ecosystem of the James Bay lowland, Wetlands, 13, 270-276, 1993.

Lafleur, P. M. and Rouse, W. R.: The influence of surface cover and climate on energy partitioning and evaporation in a subarctic wetland, Bound. Lay. Meteorol., 44, 327-347, 1988.

Lafleur, P. M. and Rouse, W. R.: Energy partitioning at treeline 
forest and tundra sites and its sensitivity to climate change, Atmos. Ocean, 33, 121-133, 1995.

Leuning, R., Ohtaki, E., Denmead, O. T., and Lang, A. R. G.: Effects of heat and water vapor transport on eddy covariance measurement of $\mathrm{CO}_{2}$ fluxes, Bound. Lay. Meteorol., 23, 209-222, 1982.

Mackay, J. R.: The Mackenzie Delta area, N. W. T., Department of Mines and Technical Surveys, Ottawa, Canada, Geographical Branch Memoir 8, 202 pp., 1963.

Mano, M.: Study on the budget of carbon dioxide and methane at an arctic coastal wet sedge tundra, Ph.D. thesis, Chiba Univ., Chiba, Japan, 2003 (in Japanese).

McFadden, J. P. and Chapin III, F. S.: Subgrid-scale variability in the surface energy balance of arctic tundra, J. Geophy. Res., 103, 28947-28961, 1998.

McFadden, J. P., Eugster, W., and Chapin III, F. S.: A regional study of the controls on water vapor and carbon exchange in arctic tundra, Ecology, 84, 2762-2776, 2003.

McNaughton, K. and Jarvis, P. G.: Predicting effects of vegetation changes on transpiration and evaporation, in: Water deficits and plant growth, Vol. VII, edited by: Koslowski, T. T., Academic Press, NY, 1-47, 1983.

Mendez, J., Hinzman, L. D., and Kane, D. L.: Evapotranspiration from a wetland complex on the Arctic Coastal Plain of Alaska, Nord. Hydrol., 29, 303-330, 1998.

Miller, P. C. and Tieszen, L.: A preliminary model of processes affecting primary production in the Arctic tundra, Arctic Alpine Res., 4, 1-18, 1972.

Minke, M., Donner, N., Karpov, N., De Klerk, P., and Joosten, H.: Distribution, diversity, development and dynamics of polygons mires: Examples from Northeast Yakutia (Siberia), Peatlands Int., 1, 36-40, 2007.

Monteith, J. L.: Evaporation and the environment, Symp. Soc. Exp. Biol., 19, 205-234, 1965.

Monteith, J. L.: Principles of Environmental Physics, Edward Arnold, London, 1973.

Moore, C. J.: Frequency response corrections for eddy correlation system, Bound. Lay. Meteorol., 37, 17-35, 1986.

Moritz, R. E.: On a possible sea-breeze circulation near Barrow, Alaska, Arctic Alpine Res., 9, 427-431, 1977.

Myers, J. P. and Pitelka, F. A.: Variations in summer temperature patterns near Barrow, Alaska: Analysis and ecological interpretation, Arctic Alpine Res., 11, 131-144, 1979.

Oechel, W. C. and Sveinbjörnsson, B.: Photosynthesis of Arctic Bryophytes, in: Vegetation and Production Ecology of an Alaskan Arctic Tundra, edited by: Tieszen, L. L., Springer Verlag, NY, 1978.

Oechel, W. C. and van Cleve, K.: The role of bryophytes in nutrient cycling in the taiga, in: Forest ecosystems in the Alaskan taiga: A synthesis of structure and function, edited by: van Cleve, K., Chapin III, F. S., Flanagan, P. W., Viereck, L. A., and Dyrness, C. T., Springer-Verlag, NY, 121-137, 1986.

Oechel, W. C., Vourlitis, G. L., Hastings, S. J., Ault, R. P., and Bryant, P.: The effects of water table manipulation and elevated temperature on the net $\mathrm{CO}_{2}$ flux of wet sedge tundra ecosystems, Glob. Change Biol., 4, 77-90, 1998.

Olivas, P. C., Oberbauer, S. F., Tweedie, C. E., Oechel, W. C., and Kuchy, A.: Responses of $\mathrm{CO}_{2}$ flux components of Alaskan Coastal Plain tundra to shifts in water table, J. Geophys. Res.,
115, G00I05, doi:10.1029/2009JG001254, 2010.

Price, J.: Evaporation from a blanket bog in a foggy coastal environment, Bound. Lay. Meteorol., 57, 391-406, 1991.

Price, J., Edwards, T. W. D., Yi, Y., and Whittington, P. N.: Physical and isotopic characterization of evaporation from Sphagnum moss, J. Hydrol., 369, 175-182, 2009.

Priestley, C. H. B. and Taylor, R. J.: On the assessment of surface heat flux and evaporation using large-scale parameters, Mon. Weather Rev., 100, 81-92, 1972.

Rastorfer, J. R.: Composition and bryomass of the moss layers of two wet-tundra meadow communities near Barrow, Alaska, in: Vegetation and Production Ecology of an Alaskan Arctic Tundra, edited by: Tieszen, L. L., Springer-Verlag, NY, 169-184, 1978.

Rouse, W. R., Hardill, S. G., and Lafleur, P.: The energy balance in the coastal environment of James and Hudson Bay during the growing season, J. Climatol., 7, 165-179, 1987.

Rouse, W. R., Carlson, D. W., and Wieck, E. J.: Impacts of summer warming on the energy and water balance of wetland tundra, Climatic Change, 22, 305-326, 1992.

Rovansek, R. J., Hinzman, L. D., and Kane, D. L.: Hydrology of a tundra wetland complex on the Alaskan Arctic Coastal Plain, USA, Arctic Alpine Res., 28, 311-317, 1996.

Ryu, Y., Baldocchi, D. D., Ma, S., and Hehn, T.: Interannual variability of evapotranspiration and energy exchange over an annual grassland in California, J. Geophys. Res., 113, D09104, doi:10.1029/2007JD009263, 2008.

Shiklomanov, N. I., Streletskiy, D. A., Nelson, F. E., Hollister, R. D., Romanovsky, V. E., Tweedie, C. E., and Brown, J.: Decadal variations of active-layer thickness in moisturecontrolled landscapes, Barrow, Alaska, J. Geophys. Res., 115, G00I04, doi:10.1029/2009JG001248, 2010.

Shulski, M. and Wendler, G.: Climate of Alaska, University of Alaska Press, Fairbanks, AK, 216 pp., 2007.

Stewart, J. B. and Thom, A. S.: Energy budget in pine forest, Q. J. Roy. Meteor. Soc., 99, 154-170, 1973.

Stoner, W. A. and Miller, P. C.: Water relations of plant species in the wet coastal tundra at Barrow, Alaska, Arctic Alpine Res., 7, 109-124, 1975.

Tanner, C. B. and Thurtell, G. W.: Anemoclinometer measurements of Reynolds stress and heat transport in the atmospheric surface layer, University of Wisconsin, USA, available from US Army Electronic Command, Atmospheric Sciences Laboratory, Ft. Huachuca, AZ 85613., Tech Rep. ECOM-66-G22-F, 82 pp., 1969.

Thom, A. S.: Momentum, mass, and heat exchange of plant communities, in: Vegetation and the Atmosphere, Vol. 1, edited by: Monteith, J. L., Academic Press, NY, 57-110, 1975.

Tieszen, L. L.: Vegetation and production ecology of an Alaskan Arctic tundra, Ecological Studies, Springer-Verlag, New York, NY, 1978.

van Genuchten, M. T. A.: Closed-form equation for predicting the hydraulic conductivity of unsaturated soils, Soil Sci. Soc. Am. J., 44, 892-898, 1980.

Vörösmarty, C. J., Hinzman, L. D., Peterson, B. J., Bromwich, D. H., Hamilton, L. C., Morison, J., Romanovsky, V. E., Sturm, M., and Webb, R. S.: The hydrologic cycle and its role in Arctic and global environmental change: A rational and strategy for synthesis study, Arctic Res. Consortium of the US, Fairbanks, AK, Report, 84 pp., 2001. 
Vourlitis, G. L. and Oechel, W. C.: Landscape scale $\mathrm{CO}_{2}, \mathrm{H}_{2} \mathrm{O}$ vapor and energy flux of moist-wet coastal tundra ecosystem over two growing seasons, J. Ecol., 85, 575-590, 1997.

Walker, D. A., Raynolds, M. K., Daniels, F. J. A., Einarsson, E., Elvebakk, A., Gould, W. A., Katenin, A. E., Skholod, S. S., Markon, C. J., Evgeny, S., Moskalenko, N. G., Talbot, S. S., and Yurtsev, B. A.: The circumpolar arctic vegetation map, J. Veg. Sci., 16, 267-282, 2005.

Walsh, J. E.: Measurement of the temperature, wind, and moisture distribution across the northern coast of Alaska, Arctic Alpine Res., 9, 175-182, 1977.

Walsh, J. E.: Climate of the Arctic Marine Environment, Ecol. Appl., 18, 3-22, 110, 2008.

Webb, E. K., Pearman, G. I., and Leuning, R.: Correction of flux measurements for density effects due to heat and water vapor transfer, Q. J. Roy. Meteor. Soc., 106, 85-100, 1980.

Webber, P. J.: Tundra primary productivity, in: Arctic and Alpine Environments, edited by: Ives, J. D. and Barry, R. G., Methuen, London, UK, 445-473, 1974.

Webber, P. J.: Spatial and temporal variation of the vegetation and its productivity, in: Vegetation and Production Ecology of an Alaskan Arctic Tundra, edited by: Tieszen L. L., SpringerVerlag, NY, 37-112, 1978.

Wilson, K., Goldstein, A., Falge, E., Aubinet, M., Baldocchi, D., Berbigier, P., Berndorfer, C., Ceulemans, R., Dolman, H., Field, C., Grelle, A., Ibrom, A., Law, B. E., Kowalski, A., Meyers, T., Moncrieff, J., Monson, R., Oechel, W., Tenhunen, J., Valentini, R., and Verma, S.: Energy balance closure at FLUXNET sites, Agr. Forest Meteorol., 113, 223-243, 2002.
Woo, M.-K., Young, K. L., and Brown, L.: High-Arctic patchy wetlands: Hydrologic variability and their sustainability, Phys. Geogr., 27, 297-307, 2006.

Woo, M. K., Kane, D. L., Carey, S. K., and Yang, D.: Progress in permafrost hydrology in the new millennium, Permafrost Periglac., 19, 237-254, 2008.

Yang, D., Goodison, B. E., Ishida, S., and Benson, C.: Adjustment of daily precipitation data of 10 climate stations in Alaska: Applications of world meteorological organization intercomparison results, Water Resour. Res., 34, 241-256, 1998.

Zona, D., Oechel, W. C., Kochendorfer, J., Paw U, K. T., Salyuk, A. N., Olivas, P. C., Oberbauer, S. F., and Lipson, D.: Methane fluxes during the initiation of a large-scale water able manipulation experiment in the Alaskan Arctic tundra, Global Biogeochem. Cy., 23, GB2013, doi:10.1029/2009GB003487, 2009.

Zona, D., Oechel, W. C., Peterson, K. M., Clements, R. J., Paw, K. T., and Ustin, S. L.: Characterization of the carbon fluxes of a vegetated drained lake basin chronosequence on the Alaskan Arctic Coastal Plain, Glob. Change Biol., 16, 18701882, doi:10:1111/j.1365-2486.2009.02107.x, 2010.

Zona, D., Oechel, W. C., Richards, J. H., Hastings, S., Kopetz, I., Ikawa, H., and Oberbauer, S.: Light stress avoidance mechanisms in Sphagnum dominated wet coastal Arctic tundra ecosystem in Alaska, Ecology, 9, 633-644, 2011. 